\title{
o8. Çocuk kitaplarında çatışma söylemi: Alacağınız Olsun
}

\section{Duygu AK BAŞOĞUL'}

APA: Ak Başoğul, D. (2021). Çocuk kitaplarında çatışma söylemi: Alacağınız Olsun. RumeliDE Dil ve Edebiyat Araşttrmaları Dergisi, (24), 128-145. DOI: 10.29000/rumelide.990104.

$\ddot{\mathbf{O} z}$

Kişiler, iletişim sürecinde karşılıklı konuşma sırasında birçok farklı nedenden dolayı çeşitli anlaşmazlıklar, uyuşmazlıklar yaşayıp çatışabilirler. Bu çatışma, kişilerarası çatışma olarak adlandırılır. Kurguya dayalı metin ya da anlatılarda da türün özelliği gereği olay örgüsü, çatışmalar üzerinden yürütülür. Yani çatışması olmayan nitelikli bir kurgusal metin düşünülemez. Dolayısıyla bu tip metinlerde çatışma içerikli konuşmalara sık rastlanması olağandır. Benzer türde oluşturulmuş çocuk yazını ürünlerinde de kişilerarası çatışmalara ve diyaloglarına sıklıkla yer verilir. Çocuk okur bu konuşmalar üzerinden öykü, roman vb. karakterleriyle özdeşim kurarak çatışmayı ve çözüm yollarını izler. Bu noktada barış eğitimi kapsamında çatışmanın yapıcı yollarla çözümlenmesi önemsenir; fakat yanı sıra çocuğun günlük yaşamda sağlıklı iletişim kurabilen bir birey olarak yetişebilmesi için çatışma söyleminin de farkında olması gerekir. Bu nedenle Türkçe derslerinde çatışmanın başlangıç, sürdürülüş ve sonlandırılışına yönelik söylemsel görünümleri göstermeyi hedefleyen okuma ve çözümlemelerin gerçekleştirilmesi önem taşımaktadır. Söz konusu gerekçeyle araştırmada Dursun Ege Göçmen'e ait Alacağınız Olsun adlı öykü kitabında yer alan çatışma içerikli karşılıklı konuşmaların söylem çözümlemesi yapılmıştır. Çözümleme sayesinde çocuk kitaplarında çatışma söyleminin hangi kişisel adımlar, dilbilimsel araç-gereçler/açıklamalar ve stratejiler kullanılarak kurulup sürdürüldügü iletişim ilkeleri de temel alınarak belirlenmiştir. Çocuk-çocuk, çocuk-yetişkin, yetişkin-yetişkin çatışmalarını içeren yapıtta, çatışmaların ağırlıklı olarak iddia/suçlama-itiraz/inkâr-karşı saldırı/savunma-karşı iddia/suçlama biçiminde saldırı-savunma veya saldırı-karşı saldırı döngüsü içerisinde tırmandırılarak sürdürüldüğü, genellikle taraflardan birinin (yetişkin) ya da üçüncü tarafın (yetişkin) yeniden düzenleme yani müdahalesiyle sonlandırıldığı sonucuna ulaşılmıştır.

Anahtar kelimeler: Çocuk kitapları, Alacağınız Olsun, çatışma içerikli konuşma, söylem, konuşma çözümlemesi

\section{Conflict discourse in children's books: Alacağınzz Olsun}

\begin{abstract}
During the communication process, people may experience various disagreements and controversies for many different reasons during dialogue. This conflict is called interpersonal conflict. In fictional texts or narratives, the plot is carried out through conflicts due to the characteristics of the genre. In other words, a qualified fictional texts without conflict is unthinkable. Therefore, it is common to encounter conflict talks in such texts. Interpersonal conflicts and dialogues are frequently included in children's literature works created in a similar genre. Through these conversations, the child reader monitors conflict and solutions through identify with the characters of stories, novels, etc. At this
\end{abstract}

Öğr. Gör. Dr., İstanbul Üniversitesi-Cerrahpaşa, Hasan Âli Yücel Eğitim Fakültesi, Türkçe Eğitimi ABD (İstanbul, Türkiye), duygu.akbasogul@iuc.edu.tr, ORCID ID: oooo-0003-4065-2030 [Araştırma makalesi, Makale kayıt tarihi: 27.07.2021-kabul tarihi: 20.09.2021; DOI: 10.29000/rumelide.990104]

Adres | Address

RumeliDE Dil ve Edebiyat Araştırmaları Dergisi $\quad$ RumeliDE Journal of Language and Literature Studies Osmanağa Mahallesi, Mürver Çiçeği Sokak, No:14/8 Osmanağa Mahallesi, Mürver Çiçeği Sokak, No:14/8 Kadıköy - ÍSTANBUL / TÜRKIYE 34714 Kadıköy - ISTANBUL / TURKEY 34714 e-posta: editor@rumelide.com e-mail: editor@rumelide.com, tel: +90 $5057958124,+902167730616$ phone: +90 505 7958124, +90 2167730616 
point, it is important to resolve the conflict in a constructive way within the scope of peace education. However, in order for the child to grow up as an individual who can communicate in a healthy way in daily life, child must be aware of the conflict discourse. For this reason, it is important to carry out readings and analyzes that aim to show the discursive aspects of the beginning, perpetuation and ending of the conflict in Turkish lessons. For this reason, the discourse analysis of the conflict talks in the story book named "Alacağını Olsun" by Dursun Ege Göçmen was carried out. Thanks to the analysis, which personal moves, linguistic markers/expressions and strategies are used to establish and maintain the discourse of conflict in children's books determined on the basis of the communication principles. In the work that includes child-child, child-adult, adult-adult conflicts, it is generally observed that the conflicts are maintained by escalating within the attack-defense or attack-counter attack cycle in the form of claim/blame-denial-counter attack/defense-counter claim/blame, it is generally concluded that it is terminated by the intervention of one of the parties (adult) or a third party (adult).

Keywords: Children's Books, Alacağınız Olsun, conflict talk, discourse, conversation analysis

\section{Giriş}

Sosyal yaşam içerisinde bireyler birbirleriyle iletişim kurup etkileşim içerisinde yaşarlar ve iletişim sürecinde kişiler çoğu zaman karşılıklı konuşurken bilinçsizce de olsa nitelik (doğruyu söyleme), nicelik (yeteri kadar aktarma), alaka (konuyla ilişkili sözceleme) ve tarz (açık ve net ifade etme) gibi söyleşi yani işbirliği ilkelerine uyarlar (Akt. Çakır, 2014: 61). İletişim ilkeleri olarak da değerlendirilebilecek bu ilkeler şöyle ayrıntılandırılabilir: karşıdaki konuşurun sözcelerini yorumlarken kibarlık, saygı, hoşgörü, cömertlik, llımlılık gösterme; profesyonelce eleştiri yapma ve gelen eleştirileri kabul etme; kendi düşüncesini değiştirebilme; kişisel gerekçe ve ihtiraslardan bağımsız davranma; topluluk önünde yapılan konuşmalarda kızgınlık, tedirginlik gibi duyguları kontrol edebilme; saygısızlık içeren ifadelerden ve kişisel adımlardan kaçınma. Öç alma, kavgacı, gururlu ve kibirli olma ile kışkırtma, sözcükleri yanlış yerde kullanma, yanlış anlama ve yorumlama ise iletişim ilkelerine yönelik bazı karşıt tutumlardır (Gloning, 2005; Karahan, 2009: 17). Dolayısıyla böyle durumlarda çatışma yaşanması olasıdır.

Eğer kişiler birbirleriyle konumsal olarak uyumsuzluk yaşamaktaysa, sözler yanlış anlaşllıp yorumlandıysa ya da kişi(ler) diğer kişi ya da kişilere saldırıya geçtiyse diğer kişi(ler) de karşı saldırı veya savunmaya geçebilir. Dolayısıyla çatışma başlar (Gloning, 2005: 266, 270). Çatışma sırasında kişiler; saldırma (aşağılama, hakaret, küçültücü suçlamalar, iftira), gizil olarak saygınlık zedelemeçelişme, dinleyiciye/izleyiciye/hakeme/egemen güce hitap etme, kişisel (art)niyetler yükleme, bilgilendirme ve çatışmayı hareketlendirme, duygu ve kişisel değerlendirmeleri açıklama, duygu ve kişisel değerlendirmelere saplanma, açıça geri adım atma (taviz, yeniden düzenleme) gibi kişisel adımlara başvururlar (Gloning, 2005). Bu bağlamda çatışmalar, zıtlıklar, polemikler, tartışmalar; bireylerarası anlaşmazlığı ve uyuşmazlı̆̆ı gösteren konuşma olayları olarak değerlendirilebilir (Karahan, 2009: 11).

Üç psikolojik eğilim kaynaklı olarak iletişim sürecinde çatışmaların yaşanması kaçınılmazdır (Jensen Campbell \& Graziano, 2005: 165-166):

1) Kişilerin tutum, inanç, bilgi ve deneyimleri farklılık gösterir,

2) Sıralanan farklılıklar kişileri benmerkezci olmaya iter ve bu nedenle kişiler, çoğu zaman başkalarının bakış açılarını algılamakta güçlük çekerler,

Adres | Address

RumeliDE Dil ve Edebiyat Araştırmaları Dergisi Osmanağa Mahallesi, Mürver Çiçeği Sokak, No:14/8 Kadıköy - ISTANBUL / TÜRKIYE 34714 e-posta: editor@rumelide.com tel: +90 $5057958124,+902167730616$
RumeliDE Journal of Language and Literature Studies

Osmanağa Mahallesi, Mürver Çiçeği Sokak, No:14/8

Kadıköy - ISTANBUL / TURKEY 34714

e-mail: editor@rumelide.com,

phone: +90 5057958124, +90 2167730616 
3) Kişiler genellikle kendi çıkarlarını korumak ve geliştirmek için motive olurlar.

Johnson ve Johnson'a göre (Akt. Ozan Demir, 2009: 28) çatışmalar kişiler arasındaki ilişkilerin güçlenip zenginleşmesini sağlayan, ilişki kurma sürecinde güdülenmeyi artıran, yaşamı ilginç ve eğlenceli kılarak tekdüzelikten kurtaran, merak duygusunu tetikleyen, kişinin kendisini tanıyıp değişmesine yardım eden kişisel iletişim biçimleridir. Dolayısıyla iletişim sırasında anlaşmazlıkların, uyuşmazlıkların, zıtlıkların, polemiklerin, tartışmaların, karşı çıkışların, çatışmaların olması normal ve doğal olarak kabul edilebilir. Önemli olan iletişim ilkeleri bağlamında bu çatışmaların barışçıl yollarla yapıcı olarak çözüme kavuşturulmasıdır. Bu durum barış eğitimi bağlamında da önem taşımaktadır. Vuchinich'e göre (1987: 598-599) teslimiyet, karşı tarafın konumunu, iddiasını, haklılı̆̆ını kabullenme; fikir birliği sağlama, uzlaşma, taviz, anlaşma, ortak noktada buluşma gibi yollara başvurularak çatışmalar çözümlenebilir; fakat kimi zaman da çözümsüzlük nedeniyle soğuk davranma, mesafe koyma, ortamdan uzaklaşma, geri çekilme; üçüncü bir tarafa, egemen güce başvurma, dışarıdan müdahale, arabuluculuk gibi yollara başvurularak yalnızca çatışma sonlandırılır.

Mayer (2000) yalnızca çatışmayı çözmeye odaklanmanın yeterli olmadığını yanı sıra kişilerin bir çatışma içerisinde olduklarını da kabullenmeleri gerektiğini ileri sürmüştür. Ona göre çatışma; bilişsel (algı), duyuşsal (duygu) ve davranışsal (eylem) olmak üzere üç boyuttan oluşur. Bir dizi algı olarak çatışma; kişinin kendi gereksinim, çıkar, istek veya değerlerinin bir başkasınınkiyle uyumsuz olduğuna dair bir inanç veya anlayıştır ve bu duruma ilişkin duygusal tepkiyi de içerir. Hissedilen duygular korku, üzüntü, acı, öfke, umutsuzluk veya bunların bir karışımı olabilir. Çatışma aynı zamanda duygu, algıların ve gereksinimlerin bir başkası pahasına gerçekleşmesi için doğrudan bir girişimi veya eylemleri de içerebilir. Bu davranış kimi zaman güç gösterisi ve şiddet biçiminde ya da yıkıcı olabilirken tersine kimi zaman da uzlaştırıcı, yapıcı ve arkadaşça olabilir. Hangi eylemin seçileceği kişiden kişiye değişebilmektedir.

Çatışma sözcügünün sahip olduğu anlamlar, Türkçe Bilim Terimleri Sözlüğüne göre (2011: 233-234) şöyledir:

(Alm. Konflikt, m; Fr. conflit, m; İng. conflict; esk. tesadüm) 1. eğitb. Aynı anda çıkan birbirine karşıt ya da eşit derecede çekici dilek ve isteklerin bireyde yarattığı ruhsal durum ve bunun yol açtığı sıkıntılar. 2. göst. yazb. Birey - birey ya da birey - toplum gibi öğeler arasındaki karşıtlıklardan ya da bireydeki ruhsal süreçlerin kargaşasında ortaya çıkan, kurmaca yapıtların omurgasını oluşturan, olay örgüsünün gelişimini sağlayan, iyi - kötü, görev - kişisel çıkar gibi karşıtlıklar. 3.topb. Birey ya da toplulukların aynı değer ya da nesneyi elde etmek ya da öteki üzerinde gücünü kabul ettirmek için yarışma, çarpışma, kavga gibi biçimler alabilen bilinçli savaşım.

Çocuk yazınının temel öğelerinden ve büyük ölçekli yapı unsurlarından biri olan konunun yapılandırılmasında olayda yer alan çatışmalar önemli rol oynar. "Çocuklara seslenen edebiyat yapitlarında yazarlar, konuyu oluşturabilmek için, yaratıcı güçlerini kullanarak bir olay kurgular. Kurgulanan her olayda bir çatışmanın yaşanması kaçınılmazdır" (Sever, 2012: 127). Özdemir de (2002: 113-114) öykü, roman ve tiyatroda kişilerin kendileriyle, başkalarıyla ya da çevreleriyle çatışmasını olay olarak tanımlamış, olay örgüsünün bir ana sorun odağında ilerleyip geliştiğine dikkat çekmiştir. Yani olay; bir çatışma ya da çatışmalar dizisi olarak nitelendirilebilir. Çocuk yazını ürünleri de "gerçekliğin, yeniden kurgulanarak çocuğa uygun biçimde yansıtılışı olması nedeniyle, çocuğun başkalarıyla yaşadığı kimi çatışmaları yansıtır" (Aslan, 2006: 197). Dolayısıyla bu tür metinlerde çocuk-yetişkin, çocuk-çocuk, yetişkin-yetişkin arasında geçen çatışma içerikli konuşmaların sıklıkla yer alması olağandır.

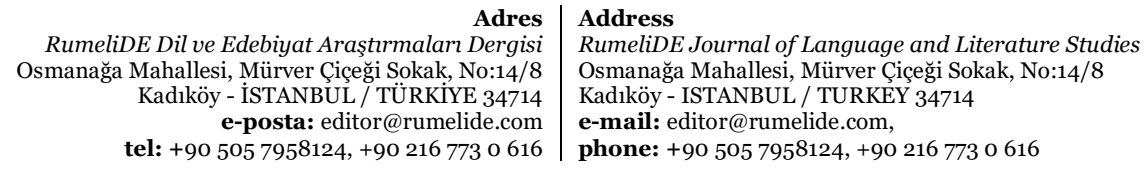


Kişinin bir başkasıyla çatışması çocukların hoşlandığı bir çatışma tipidir. İnsan-insan, insan-hayvan veya hayvan-hayvan arasındaki çatışmalarda çocuklar, özdeşim kurdukları insan veya hayvan karaktere bağlı devinimsel biçimde ilerleyen çatışmaları merakla izlerler. Karakterin olası yenilişi gerilimi artırırken onun her durumdan kıl payı kurtuluşu ise çocuğu rahatlatır ve karaktere karşı bir sempati duymasını sağlar (Solak, 2013: 229). Çocuklar için yazılmış nitelikli metin ya da yapıtlarda okuma ediminden zevk alınabilmesi için çocuğun çatışmayı yaşayan karakter(ler)le özdeşim kurup öykülenen olaydaki gerilimi duyumsayabilmesi gerekmektedir (Sever, 2012: 128). Erken yaşlardan itibaren nitelikli kurgusal metinlerle karşılaşan çocukların günlük yaşamdaki iletişim süreçlerinde yaşadıkları çatışmalara yönelik sorun çözme becerileri de gelişecektir; çünkü kurgusal metinlerdeki karakterleri örnek alıp onlarla özdeşim kurabilen çocuk, herhangi bir çatışma ile karşılaşması durumunda bu karakterleri örnek alarak yeni ve farklı çözümler üretebilir (Yakar ve Yılmaz, 2015: 58). Dolayısıyla okul türü öğrenmede kurgusal metinlerde yer alan kişinin kendisiyle, başkalarıyla, doğayla ya da toplumla çatışmasına (Sever, 2012: 128) yönelik çözümlemelere ve ilişkili etkinlik ile görevlere yer verilmesi bu açıdan oldukça önemlidir. Dilidüzgün ve diğerlerinin (2019a: 171) metin türüne özgü okuma eğitimi üzerine gerçekleştirdikleri çalışmada da yazınsal ve kurgusal bir metin türü olan öykü türü üzerinden, etkinleştirilen biçimsel şemadan/tür bilgisinden yararlanma üstbilişsel okuma stratejisini işletmek amacıyla geliştirilen etkinlikte çatışma ve nasıl çözümlendiğini tahmin etmeye yönelik görevlere yer verilmiştir.

Türkçe derslerinde çatışma çözümüne yönelik etkinliklere ve görevlere yer verilmesi önemlidir. "Öğretmen, öğrencilerinden öykülerdeki çatışmaların çözümlerini değerlendirmelerini ve kendi çözüm biçimlerini söylemelerini/yazmalarını isteyebilir. Böylece edebiyat, birçok karakterin tepkileri arasında, çocukların bir sorunun farklı yönlerini düşünmelerine ve sorun çözme becerilerini geliştirmelerine de yardımcı olur" (Aslan, 2014: 387); fakat öncesinde -özellikle barış eğitimi kapsamında- öğrencilere kurguya dayalı metinlerde, konuşmalar üzerinden sunulan çatışma söyleminin nasıl oluşturulup sürdürüldüğünün dilsel görünümlerinin de fark ettirilmesi gerekmektedir. Bu sayede öğrenci, günlük yaşamda diğer kişilerle iletişim kurarken çatışma içerisinde olduğunun farkına varır ve çatışma içerikli konuşmayı sağlıklı ve yapıcı bir biçimde yönetmeyi, sonuçlandırmayı öğrenebilir. Aksi durumda bir çatışmada olduğunun bilincinde olmayan çocuğun, süreci sağlıklı bir biçimde yani iletişim ilkelerini dikkate alarak yönetebilmesi mümkün olmayabilir. Bu açıdan bakıldığında Türkçe derslerinde kurgusal metinlerden hareketle çatışmaların söylemsel görünümlerini belirlemeye ve fark etmeye yönelik söylem çözümlemelerinin gerçekleştirilmesinin gerekliliği açıktır.

Tüm bu kuramsal çerçeve odağında çalışmada Dursun Ege Göçmen'e ait öykü türünde bir yapıt olan Alacağını Olsun'daki çatışma içerikli karşılıklı konuşmaların Gloning'in (2005) önerdiği kişisel adımlar, bu bağlamda kullanılan stratejiler ve dilbilimsel araç-gereçler/açıklamalar ile iletişim ilkeleri bakımından çözümlenerek çocuk kitaplarında çatışma söyleminin nasıl bir görünüm sergilediğinin belirlenmesi amaçlanmıştır. Araştırmada gerçekleştirilen söylem çözümlemelerinin Türkçe ve sınıf öğretmenlerine, türe özgü okuma eğitimi bağlamında diğer kurgusal metinlerde yer alan çatışma içerikli konuşmaların çözümlenmesi bakımından yardımcı ve örnek olacağı düşünülmektedir.

\section{Yöntem}

Çalışmada tümevarımsal ve tümdengelimci veri çözümlemeye, kastedilen anlama odaklanmaya, derinlemesine düşünmeye olanak sağlaması ve gelişim gösteren bir süreç ile bütüncül bir anlayışı içermesi gibi özellikleri nedeniyle nitel araştırma yöntemi benimsenmiştir (Creswell, 2014: 186).

\footnotetext{
Adres | Address

RumeliDE Dil ve Edebiyat Araştırmaları Dergisi $\quad$ RumeliDE Journal of Language and Literature Studies Osmanağa Mahallesi, Mürver Çiçeği Sokak, No:14/8 $\quad$ Osmanağa Mahallesi, Mürver Çiçeği Sokak, No:14/8 Kadıköy - ÍSTANBUL / TÜRKIYE 34714 Kadıköy - ISTANBUL / TURKEY 34714 e-posta: editor@rumelide.com e-mail: editor@rumelide.com, tel: +90 505 7958124, +90 2167730616 phone: +90 505 7958124, +90 2167730616
} 


\section{Araştırmanın deseni}

Araştırmada nitel araştırma desenlerinden biri olan söylem çözümlemesinden yararlanılmıştır. Söylem çözümlemesi, dilin bireysel kullanımını ya da her türlü eylemi üretim koşulları içinde inceleyip belli bir anı ilgilendiren her türlü dilsel etkinliğin betimlenmesi, işlevlerin ortaya konması işidir (Günay, 2013: $17,22)$.

\section{Verilerin toplanması ve çözümlenmesi}

Dursun Ege Göçmen tarafindan kaleme alınan Alacağınız Olsun adlı yapıt, ilkokul dördüncü sınıfta öğrenim gören 10 yaşındaki çocukların yaşamlarından kesitler içeren öykülerden oluşan, dolayısıyla kurmaca nitelikli bir çocuk kitabıdır. Çalışmanın verileri bu yapıttan elde edilmiştir. Söz konusu yapıt 2008 Rıfat Ilgaz Öykü Yarışması Başarı Ödülünü kazanmıştır. Dolayısıyla çocuk yazını ürünlerinden beklenen temel ilkeleri taşıdığı düşünülen bu yapıt, içerisinde çokça çatışma içerikli konuşma barındırması nedeniyle araştırma kapsamına alınmıştır. Bu bağlamda çalışmada amaçlı örnekleme yöntemlerinden ölçüt örneklemeye başvurulduğu söylenebilir. Ölçüt örneklemede araştırma amacı, problemiyle ilgili kişiler, olaylar, nesneler ya da durumlara ilişkin nitelikler yani ölçütler belirlenerek örneklem oluşturulur (Büyüköztürk, 2012: 11).

Verilerin toplanması aşamasında doküman incelemesinden yararlanılmıştır. Öncelikle seçilen yazınsal yapıttaki çatışma içerikli konuşmalar taranmış ve "Anlayışla gülümsedi Sedat öğretmen (15).", "Annem yüzüme garip bir ifadeyle bakarak yanıt verdi (49)." gibi açıklamalar ile "dedi, diye söyledi, diyerek konuşmasına devam etti, dedim anlayışla" vb. aktarım ifadeleri çıkarılarak makaleye aktarılmıştır. Yapıtta kişilerin kendileriyle olan çatışmalarına da sıklıkla rastlansa da bu söylemler, karşılıklı konuşma biçiminde olmamaları nedeniyle çalışmaya dahil edilmemiştir. Yani çalışma, yalnızca kişilerarası çatışma içeren karşılıklı konuşmalar ile sınırlandırılmıştır.

Kimi araştırmacılar tarafindan (bk. Yemenici, 1995; Coulthard, 2002; Sinclair and Coulthard, 2002; Fairclough, 2006; Gür, 2011; Çubukçu, 2014) söylem çözümlemesi ulamı altında sunulan konuşma çözümlemesinden bu çalışmada verilerin çözümlenmesi aşamasında yararlanılmıştır. Bu çözümleme yönteminde iletişimin en yaygın biçimi olan konuşma üzerinden, dil aracılığıyla bağlamın nasıl oluşturulduğu, bağlamın ise dili hangi yönde, nasıl etkilediği incelenir (Kocaman, 2009: 8). Konuşma çözümleyiciler konuşmaların açılış ve kapanışlarını; kavşakları; konu oluşum, gelişim ve değişimini; öyküleştirme biçimlerini; özetlemek, ima etmek vb.'nin nasıl ve niçin formülleştirildiğini, söz alma ve sıra değişimlerinin nasıl gerçekleştiğini incelerler (Fairclough, 2006: 16-17). Çözümleme yapılırken çatışma içerikli söylemler bu ölçütler dikkate alınarak analiz edilmiştir; fakat incelenen konuşmaların yazar tarafından kurgulanması ve yazılı olması nedeniyle doğal bir çatışma sürecini tam olarak yansıtmadığı söylenebilir. Dolayısıyla çalışmanın bulgular bölümünde gerçekleştirilen çözümlemelerde konuşmacıların duygu durumu-değişimi, vurgu, tonlama, söz alma, söz kesme, duraksama, duraklama vb. gibi unsurlara yönelik ayrıntılara doğrudan yer verilemeyip ancak yazar tarafindan yapılan açılamalar ya da karakter(ler)in sözceleri doğrultusunda değinilebilmiştir.

Söylemleri aracılığıyla kişiler, konuşmalarında bağlam içinde, diğer kişiye karşı veya diğer kişiyle ilişkili olarak konum alırlar. Bu konumlanmalar kimi zaman doğal olarak oluşturulurken kimi zaman ise kişilerin karakter özelliklerine (baskın vb.) göre değişebilir. Yani sabit bir konumlanmadan söz edilemez, her bağlam ve konuşmada kişilerin konumlanmaları değişim gösterebilir, dolayısıyla konumlanma geçicidir. Oluşturulan konumlar kimi zaman diğer konuşmacı tarafından kabullenilir veya reddedilir.

\footnotetext{
Adres | Address

RumeliDE Dil ve Edebiyat Araştırmaları Dergisi $\quad$ RumeliDE Journal of Language and Literature Studies Osmanağa Mahallesi, Mürver Çiçeği Sokak, No:14/8 $\quad$ Osmanağa Mahallesi, Mürver Çiçeği Sokak, No:14/8 Kadıköy - ÍSTANBUL / TÜRKIYE 34714 Kadıköy - ISTANBUL / TURKEY 34714 e-posta: editor@rumelide.com e-mail: editor@rumelide.com, tel: +90 505 7958124, +90 2167730616 phone: +90 505 7958124, +90 2167730616
} 
Yani diğer konuşmacı(lar) bu bağlamda seçim yapmak durumunda kalır. Kabullenmeler sonrasında kişilerin kimlik ve/veya davranışlarında değişim ya da dönüşümler yaşanabilir (Ak Başoğul, 2018: 24; Burr, 2012: 111; Tekdemir, Arkonaç ve Çoker, 2012: 152; Van Langenhove \& Harré, 1999: 16-18). Çalışmada çatışma içerikli söylemler bu noktalar da dikkate alınarak çözümlenmiştir. Yapılan çözümlemelerin inandırıcılık ve sağlamlığını artırabilmek için ise karşılıklı konuşmalar araştırmaya doğrudan ve bağlamıyla birlikte eklenmiş, dilbilimsel unsurlar ile çatışma sırasında başvurulan stratejiler açıç̧a belirtilerek kanıtlama yoluna gidilmiştir. Yanı sıra çözümlemeler, araştırmacı tarafından farklı zamanlarda birden çok kez yapılmış ve denetlenmiştir.

\section{Bulgular}

Araştırmanın bu bölümünde hedef kitapta belirlenen çatışma içerikli konuşmaların çözümlenmesine yönelik bulgulara yer verilmiştir.

Kitabın "Her İnsanın Bir Öyküsü Vardır" adlı ilk öyküsünde öğretmen ile çocuklar arasında kitap okuma ve yazma konusunda fikir çatışması yaşanmaktadır. Çatışma öncesinde öğretmen, okuma ve yazmanın önemine dair çokça -DIr bilgisellik kipliği içeren bir giriş yapmıştır:

Uygarlık dediğimiz şey yazıyla başlamıştır. İnsanoğlu önce yaşadığı olayları başkaları okusun, bilsin, unutmasın diye yazmıştır. Sonra duygularını, umutlarını, hayallerini kayıt altına almıştır (9).

Öğretmenin yukarıdaki giriş tümcesi sonrasında kimi öğrenciler arasında bu konuya ilişkin olumsuz düşünce ve duygu durumlarını belirten fısıltılı konuşmalar gerçekleşmiştir:

\begin{tabular}{|c|c|}
\hline Kerem 1: & Şu yazıyı bulanı bir elime geçirirsem yapacağımı biliyorum ben. \\
\hline Ülken 1: & Tamam, sen yazıyı bulanı döv, ben okumayı ilk bulanın hakkından geleyim. \\
\hline Deniz 1: & $\begin{array}{l}\text { Çok âlemsiniz çocuklar. Biraz mantıklı düşünsenize... Yazıyı bulan ilk kişi aynı } \\
\text { zamanda okumayı da bulmuştur. Yazıyı bulanlar ise..." }\end{array}$ \\
\hline Doğancan 1: & Sümerlerdir! \\
\hline Kerem 2: & $\begin{array}{l}\text { Kim bulmuşsa bulmuş, bana ne! Ben okumaktan ve yazmaktan hiç } \\
\text { hoşlanmiyorum (9-10). }\end{array}$ \\
\hline
\end{tabular}

Öğretmenin bilgi verme amaçlı ilk sözcesinden sonra söz konusu sözcede verilen bilgiye Kerem'in itirazını içeren tümcesi ile çatışma sürecinin başlatıldığı görülmektedir. Kerem, yazmaya karşı olumsuz duygusunu ve kızgınlı̆̆nı yazıyı bulan kişiye saldırı içeren küçültücü bir biçemle yakın arkadaşı Ülken'e sunmuştur. Ülken de Kerem'le benzer olumsuz duygulara sahiptir; fakat o okumaktan hoşlanmamaktadır. Bu duygusunu ise fiziksel şiddet içeren ifadelerle (dövmek) aktarmıştır ve eyleme geçme konusunda arkadaşıyla ortakllk kurmuştur. Düşünce benzerliğinin sağlanmasında emir kipinden yararlanılmıştır. Gizil olarak ise okuma-yazmayı bulan kişi küçümsenmiştir. Arkadaşları Deniz ise -DIr biçimbirimini kullanıp alaycı bir biçemle onların bilgi eksikliklerini ve mantık kurma konusundaki yetersizliklerini yüzlerine vurarak onları küçümsemiştir; fakat sözü Doğancan tarafından kesilmiştir. Kerem ise bu durumdan yararlanarak okuma ve yazmaya ilişkin kendi olumsuz duygusunu yinelemiştir. Dolayısıyla duygusuna saplanıp kaldığı söylenebilir. Yanı sıra bir inkâr, kabullenmeme durumunun yaşandığı söylenebilir.

Yukarıda alıntılanan konuşma, öğretmenin kitap okuma üzerine yönelttiği tartışma odaklı sorularla devam etmiştir ve öğrenciler yanıtlarını öğretmenin beklentisini öngörerek vermişlerdir; fakat öğretmen, bu durumdan hoşnut değildir. O nedenle öğrencilerinin konuyla ilgili gerçek fikirlerini

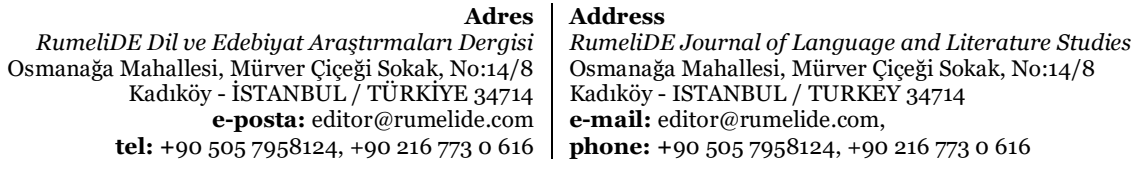


öğrenmek için başka sorular üretmiştir. Çatışmanın bu noktada seyri değişmiştir. Yukarıda alıntılanan söylemde öğretmenin tümcesi öğrencilerin çatışmalarını tetiklese de aşağıdaki söylemde öğretmen ve öğrenciler arasında konuya ilişkin çatışmanın açıkça ve doğrudan yaşandığı görülmektedir:

Öğretmen 1: $\quad$ Kerem, ne diyorsun arkadaşına? Söyle biz de duyalım.

Ülken 1: $\quad$ Hadi, cesaretin varsa öğretmene de söyle!

Kerem 1: $\quad$ Oyun diyorum öğretmenim. Bizim oyun oynamaya da ihtiyacımız var.

Öğretmen 2: $\quad$ Çok doğru söylüyorsun. Oynamak da çocukların ihtiyacı. Aferin, oturabilirsin çocuğum. Evet, çocuklar, oyun oynamak da bir ihtiyaç. Peki ya kitap okumak ve yazı yazmak ihtiyaç mıdır?

Deniz 1: $\quad$ Okumak ve yazmak ihtiyaç değil, görevdir öğretmenim.

Öğrenci 1: $\quad$ Tabii ki görevdir.

Öğrenci 2: $\quad$ Okumak ve yazmak görevdir.

Öğrenci 3: $\quad$ Hele el yazısıyla yazmak, hem zulüm hem de görevdir.

İkizler 1: $\quad$ Yemek yemek dışında her şey görevdir.

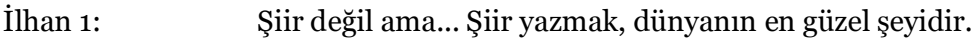

Öğretmen 3: $\quad$ Neden ihtiyaç değil de görev olduğunu düşünüyorsunuz?

Deniz 2: $\quad$ Yemek yemezsek, su içmezsek, uyumazsak ölürüz. Ama kitap okumazsak ölmeyiz.

Öğretmen 4: $\quad$ Pekiiii... oyun oynamazsanız ölür müsünüz çocuklar?

Nazlı 1: $\quad$ Ölmeyiz elbette. Ama hayattan da zevk almayız öğretmenim.

Öğretmen 5: $\quad$ Tamam işte çocuklar. Asıl konu bu! Evet çocuklar, her canll, adı üstünde, bir hayat sürüyor. Kuşlar, böcekler, çiçekler... Hepsi canlı, ama hayatı anlamlı kılmak, hayatı değiştirmeye çalışmak insana özgü bir şey. İşte kitap okumak bunu sağlıyor. Ve biliyor musunuz, her çocuk bir kitaptır. Birbirinden farklı serüvenleri olan bir kitap hem de (14-16)...

Öğretmen, alıntılanan sözcesinde de görüleceği üzere tartışmanın öğrenciler arasında döndüğünü fark etmiş ve biz dilini kullanarak Kerem'i, düşüncelerini açıç̧a sınıfın geneli için dillendirmeye davet etmiştir. Ülken, egemen güç (öğretmen) ve cesaret eksikliği nedeniyle Kerem'in, düşüncelerini açıkça ifade edemeyeceğini düşünüp Kerem'i küçümseyip suçlamıştır; fakat tam tersi yaşanmış, egemen güç Kerem'i onaylamıştır. Kerem ise bu duruma şaşırmıştır, öğretmeninden bu olumlu dönütü beklememektedir. Ardından öğretmen tarafından öğrencilere yine bir soru yöneltilmiş, Kerem'e gösterilen olumlu tavır nedeniyle öğrencilerin çoğunluğu ardı ardına konuyla ilgili fikirlerini öne sürmeye başlamışlardır. Bunda öğretmenin kibarlık, ılımlılık, anlayış, hoşgörü ve saygı gibi iletişim ilkelerini işe koşmasının etkisi olduğu söylenebilir; fakat öğrenciler, öğretmenden farklı düşünmektedirler. Onlara göre okumak ve yazmak bir gereksinim değil, görevdir. Bu görüşlerinde de DIr biçimbiriminin kullanımı dolayısıyla net oldukları söylenebilir; fakat kendi çıarlarını da göz ettikleri görülebilir; çünkü görüşlerini kişisel durumlarını da ekleyerek bildirmişlerdir. Öğretmen, bu düşüncenin arka planını öğrenmek için farklı bir soru yöneltmiştir. "Pekiiii" biçimindeki uzatma kullanımı öğretmenin düşünme sürecini yansıtmaktadır. Aynı zamanda sorusuyla tartışmayı çözüme kavuşturmak istediği açıktır. Deniz ise karşı argüman sunarak "ama" bağlacı aracılığıla gizil olarak bir zıtlık ilişkisi kurmuştur. Yani önceki düşüncesi hala geçerliğini korumaktadır. Öğretmenin çatışmanın derecesini yükseltmeye yönelik diğer sorusunu ise Nazlı yine kendi düşüncesini terk etmeyerek "ama" bağlacıyla gizil olarak desteklemiştir. Bu aşamaya kadar öğrencilerin okuma ve yazmaya ilişkin "görevdir" yargılarının değişmediği açıktır. Öğretmen ise son sözcesiyle konuyla ilgiyle bilgilendirme yaparak haklılığını vurgulamış, bir bakıma öğrencilerdeki eksik bilgileri tamamlayarak

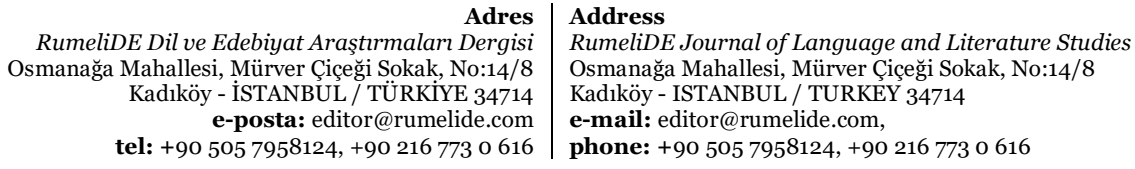


çatışmayı sonlandırıp konuyu kapatmıştır. Dolayısıyla öğretmenin de yargısını sürdürdüğü, yaptığı bu bilgilendirme sonrasında öğrencilerin fikirlerini değiştirdiğini düşündüğü söylenebilir; fakat konuşmanın devamına bakıldığında çocukların konuyu tam olarak anlamlandırabildiği söylenemez.

Öğretmen alıntılanan ilk sözcesinde de görüleceği gibi tüm konuşma ve çatışma süresince bilgilendiren, soru yöneltip tartışmaya sevk eden; fakat aynı zamanda da otorite/egemen güç konumundadır. Öğretmenin bu konumsal özelliği nedeniyle öğretmen ve öğrenciler arasında var olan fikir çatışmasında özellikle öğrencilerin görüşlerini tam ve samimi olarak aktaramadıkları, kimi zaman ise -özellikle öykünün başlarında- otorite konumunda olan öğretmenin görüşlerine koşut yani kendilerine ait olmayan fikirler ileri sürdükleri söylenebilir. Fısıldaşarak gerçekleştirilen tartışmalar, korku ve çekinceyle ileri sürülen fikirler ya da "Şişşşşt... öğretmen bu tarafa bakıyor." (11), "Hadi, cesaretin varsa öğretmene de söyle!" (14) gibi söylemlerin varlığı bu durumun kanıtı olarak ileri sürülebilir. Görüldüğü üzere çocuklar çatışma sürecini egemen güce hitap ederek düzenlemeye ve kontrol etmeye çalışmışlardır. Bu noktada çocukların zaman zaman öğretmenle zaman zamansa kendi içlerinde tartışma gerçekleştirdikleri söylenebilir.

"Dünyanın Bütün Dedeleri Birleşin!" adlı ikinci öyküde ise Ülken'in dedeleri arasında çıan çatışma ön plana çıkmaktadır. Öykünün ilk kısımlarında dedeler doğrudan karşılıklı bir çatışma içerisinde değildir, torunları aracıllğıyla birbirlerine gönderimlerde bulunmuşlardır. Bu süreçte sürekli aralarında bir yarış vardır ve üstünlük kurma çabasındadırlar; yani en iyi dedenin kendisi olduğunu kanıtlama çabasındadırlar; fakat özellikle torunları üzerinden gerçekleştirdikleri bu yarış iki dedeyi kaçınılmaz ve oldukça hızlı bir biçimde doğrudan tartışmaya yönlendirmiştir:

Recep 1: Dün akşam haberlerde dinledim, bu yıl Marmara hamsi kaynıyormuş. Ama hamsi de akıllı hayvan canım, hangi oltaya gelip hangisine gelmeyeceğini biliyor!

Suat 1: Sen kendine bak! Dün akşam bacak kadar çocuğa yeniliyordun tavlada.

Recep 2: Hadi ordan, tavlayı senden mi öğreneceğim ben?

Suat 2: Öğrenebilsen öğreteceğim ama nerde sende o kabiliyet!

Recep 3: Bana bak, bana! Sen önce hamsi tutmayı öğren, ondan sonra bana tavla dersi vermeye kalk.

Suat 3: Çok şükür! Balık da tutuyorum, tavla da oynuyorum.

Recep 4: Beşer şaşar, diye senin gibilere derler efendi! Ne çabuk unuttun 6-o yenildiğin günleri.

Suat 4: Neee? Ne diyorsun sen? Asıl sen unuttun iki mars bir ters olduğunu.

Recep 5: Ağzından çıkanı kulağın duyuyor mu senin? Sen daha tavlaya tava derken ben tavla oynuyordum. Sen oynasan oynasan kız tavlası oynarsin.

Suat 5: Ben kız tavlasını da iyi bilirim. Ama sen onu da oynayamazsın. Kız tavlası için önce sayı saymayı bilmek lazım.

Recep 6: Bana bak Suat Ağa, vallahi dünür falan dinlemem (25-26)...

Recep dedenin ilk sözcesinin de bir gönderme ifadesi olduğunu söyleyebilmek mümkündür. O gün torunuyla birlikte balık tutmaya giden Suat dedeyle eksik özellikleri (balık tutamaması - beceriksizlik) nedeniyle gizil olarak alay ederek onu küçümseyip torununun gözündeki saygınlı̆ımı zedelemekte; ama bunu kişinin adını belirterek ya da kendisine doğrudan söylemeyip ima yoluyla yapmaktadır. Önceki konuşmaların aksine bu gönderim ifadesi artık karşılıksız kalmamış ve Suat dede de ilk sözcesinde Recep dedeyi tavlada bir çocuğa yenilmesi üzerinden aşă̆ılamış, bu eksikliği üzerinden saygınlı̆̆ını zedelemeye çalışmıştır. Sonrasında da çatışmanın karşı tarafin bir eksikliğini belirterek (kabiliyetsizlik, hamsi tutmayı bilmeme, kulağın duymaması, sayı saymayı bilmeme, tavlaya tava deme)

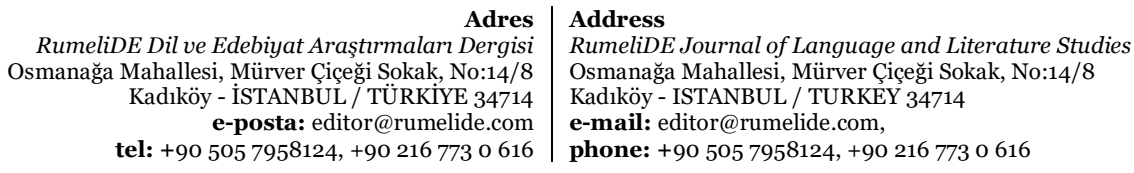


saldırı, suçlama ve suçlamayı inkâr, yalancılıkla itham biçiminde yinelemelerle sürdürüldüğü görülmektedir. Dolayısıyla iki tarafın da duygu ve değerlendirmelerine saplanıp kaldığı söylenebilir. Kışkırtma biçiminde sürekli tırmandırılarak ilerleyen bu konuşmada dedelerin tavla konusu odağında birbirlerini aşağıladıkları, argo ve tehdit içeren alaycı söylemlere de başvurdukları görülmektedir. Hatta birbirlerine fiziksel olarak da yaklaşmışlardır, yani tartışma giderek alevlenmektedir ki Recep dedenin son sözcesi bu ileri gidişi destekler niteliktedir. Söz konusu ileri gidişi fark eden Ülken'in annesi Recep dedenin sözünü kesip "çaaatt" diye masaya vurduktan sonra onları tavlada kozlarını paylaşmaya davet ederek çatışmayı bitirmiştir. Yani üçüncü bir kişinin olaya müdahalesi sonrasında yeniden düzenleme yapılarak tartışma sonlandırılmıştır.

"İntikam Dondurma Gibidir: Soğuk ve Tatlı" adlı üçüncü öyküde ise eve gelen yüksek telefon faturası nedeniyle anne-baba arasında bir çatışma yaşanmaktadır:

Baba 1: Beş yüz lira! Telefon faturası beş yüz lira! Yahu şaka gibi... Asgari ücretle çalışan bir işçinin maaşı kadar neredeyse! Kiminle ne konuşur insan bu kadar?

Anne 1: Bir yanlışlık olmasın. İtiraz etsek...

Baba 2: Ne yanlışı hanım! Kendi çocuğunu tanımıyor musun? Her akşam iki saat arkadaşıyla konuşan senin oğlun değil mi?

Anne 2: Demek şimdi benim oğlum oldu! Yaramazlık yapınca benim oğlum, aferin alınca senin oğlun. Hem erkek çocuklar babalarını örnek alır bir kere.

Baba 3: Tamam! Ona cezasını ben vereceğim. Bakalım bir daha aynı hatayı yapacak mı? Okul tatil olana kadar arkadaşlarıyla buluşmak, top oynamak, televizyon izlemek, bilgisayarda oynamak yasak Kerem'e... Ayrıca telefona da elini sürmeyecek (31-32).

Yukarıdaki çatışma öncesinde anne ve baba yüksek gelen telefon faturasını görmüş ve çok şaşırmıştır. Bunun üzerine telefon faturasının yüksek gelmesine neden olan kişi aranmaya başlanmıştır. Abla, faturanın yüksek gelmesinden sorumlu asıl kişi olmasına karşın suçu kardeşi Kerem'in üzerine atmıştır ve baba bu suçlama üzerine kızgınlıkla Kerem'i odasına göndermiştir. Ardından alıntılanan söylemde de görüleceği üzere babanın ilk sözcesinde şaşkınlk ve kızgınlı̆ııı gizleyemediği, söylenmeye devam ettiği görülmektedir. Anne ise duruma farklı bir açıdan bakıp çözüm bulmaya çalışarak yeniden düzenleme yapmaktadır; fakat babanın ikinci sözcesinde annenin sözünü keserek düşüncesinde ısrarcı olduğunu yine aynı öfkeli dille gösterdiği söylenebilir. Bu iddiasını da çocuğuyla ilgili önceki deneyimlerine dayandırarak aktarmıştır; fakat sözceden de anlaşılacağı üzere "senin oğlun" ifadesiyle annenin de gizil olarak suçlandiğı söylenebilir; baba ise saldırı yoluyla onaylamaya dayah sorular yönelterek bu durumda hakhlığımı vurgulama çabasındadır. Dolayısıyla annenin saygınlğ̆ıı zedeleme yoluna gidildiği yorumu da yapılabilir. Anne, ikinci sözcesinde kendisine bir suçlama yapıldığını fark edip bu duruma itiraz etmiş ve o da sinirlenerek babanın tutarsızhğını ileri sürmüsstür. "Hem erkek çocuklar babalarını örnek alır bir kere." iddiasıyla genelleme yaparak [-(I/A)r biçimbirimi] babanın haksızlığını, kendisinin de hakhlığını vurgulamıştır. Baba son sözcesinde geri adım atarak çatışmayı sonlandırmıştır. Yaşanan soruna yönelik çözümünü ve içeriğini aktararak yeniden düzenleme yapmıştır. Verilen cezaların ise öç almaya yönelik olduğu yorumunu yapmak mümkündür.

"Alacağınız Olsun" adlı diğer öyküde ise kardeşler ve anneleri arasında bir çatışma yaşanmıştır:

Ağabey 1: Yeteeer!

İlhan 1: N'oluyoruz ya!

Ağabey 2: Kafamı şişirme de git şiirini başka yerde oku, bücür!

İlhan 2: Annneee, abim bana vuruyoo!..

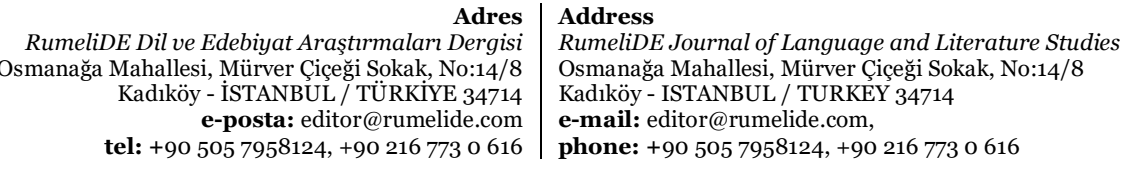


Anne 1: Oğlum niye rahat bırakmiyorsun Ayhan abini, bak test çözüyor!

İlhan 3: Zaten hep onu koruyun siz. Biz de bu evde yaşıyoruz, beğenmiyorsa o gitsin odadan.

Anne 2: Kaç kere söyleyeceğim İlhan! Abin çok önemli bir sınava hazırlanıyor.

İlhan 4: Sinava hazırlanıyormuş, hıh! Dördüncü sınıf kolay mı sanıyorsunuz?..

Anne 3: Tamam İlhan, senin de derslerin zor, ama Ayhan abin lise sınavlarına hazırlanıyor. İstediği Anadolu lisesine girebilmesi için çok çalışması lazım.

İlhan 5: Tamam işte, son yazdığım şiiri okuyup ona moral verecektim... ama iyilikten de anlamıyor ki!

Anne 4: Geç salona, babana oku şiirini... Yormayın beni oğlum, daha yemek hazırlayacağım (4546).

Konuşmanın doğrudan abinin yüksek sesle ve e ünlü sesini uzatarak isyanıyla başladığı görülmektedir. Abi, ikinci sözcesinde de görüldüğü üzere kardeşinin şiir okumasına oldukça sinirlenmiş ve İlhan'ın ilk sözcesini tam olarak aktarmasına bile izin vermeden ve hakaret edip (bücür) küçültme yaparak emir kipiyle kardeşini odasından göndermiştir. Hatta fiziksel güç de kullanmıştır. Yani abi, kardeşiyle arasında bir tartışma yaşanmasına dahi izin vermeyip yaşça büyük olma durumundan yararlanarak otorite konumunu kullanmıştır. Odasından kovulan İlhan ise ikinci sözcesiyle abisini egemen güç olan anneye şikâyet etmiştir. Sözceye bakıldığında e ve o ünlü seslerinin uzatılmasıyla bunun bir seslenme biçiminde gerçekleştĭgi söylenebilir. Anne ise kendisinden destek bekleyen çocuğunun beklentisinden farklı yönde bir yanıt vererek çatışmayı başlatmıştır. Annenin ilk sözcesine göre İlhan suçlanan ve abi savunulan kişi konumundadır. Dolayısıyla annenin bir taraf seçtiği söylenebilir. İlhan, haklılığım vurgulamak amacıyla siz ve biz dilini kullanarak kutuplaştırıcı ve ayrıştırıcı bir dille genelleme yapmıştır. Yani abi, diğerleri tarafından korunan, İlhan ise dışlanan ve yalnız konumundadır. Buna göre duygu sömürüsü yapmaya çalıştığı da söylenebilir. Anne, sınav konusunun daha önce çokça dile geldiğini, kızgınlı̆̆ını da belli ederek farklı bir sözceyle hatırlatıp yinelemiştir. İlhan dördüncü sözcesinde -hı ünleminin kullanımından da anlaşılacağı üzere- abisinin sınav hazırlı̆̆ını küçümsemiştir. -mIş biçimbiriminin bu bağlamda kullanıldığı söylenebilir. Ardından ise siz dilini kullanarak kendi içerisinde bulunduğu durumun da zorluğunu aktarmak istemiştir. Burada gizil olarak aile büyüklerine bir mesaj vermek istendiği düşünülebilir, yani ailenin de benzer olarak onun derslerini vb. küçümsediği ve İlhan'ın bu durumdan rahatsızlığını dile getirmeye çalıştı̆̆ı yorumu yapılabilir. Bir karşı çıkış ve başkaldırı vardır. Söz konusu sözce sonrası annenin sinirli tonundan vazgeçip "tamam" sözcesiyle geri adım attığı ve bilgilendirme yaparak durumu özetlediği görülmektedir. "Ama" bağlacının kullanımından da anlaşılacağı üzere her ne kadar İlhan'ın durumunu anlamaya çalışsa da gizil olarak kıyas yoluyla abinin sınav hazırlığının önemine dikkat çekmiştir. İlhan ise beşinci sözcesinde görüleceği gibi düşüncesinde ve tutumunda saplanıp kalmıştır, abisini de anlayışsızlıkla suçlamıştır. Yani hâlâ onun durumunu küçültmeye çalıştı̆̆ı açıktır. Her iki tarafın son sözcesine bakıldığında sözcelerin içeriğinin değişmediği, İlhan ve annesinin savunduklarının arkasında olduğu görülmektedir. Anne, bu durumu fark ederek ve otorite konumunu kullanarak bir çözüm önerisiyle (salona gönderme ve şiiri babasına okutma) yeniden düzenleme yapmıştır. Çatışma, taraflardan birinin otorite konumunu kullanarak ortamdan uzaklaşma sağlamasıyla sonlandırılmıştır.

"Kendi Modanı Kendin Yarat" adlı öyküde anne ve kızı arasındaki çatışma konu edilmiştir. Bu çatışma, bir kuşak çatışması olarak da değerlendirilebilir:

Nazlı 1: Anneeee...

Anne 1: Söyle kızım.

Nazlı 2: Bana o ayakkabıdan da alacak mısın?

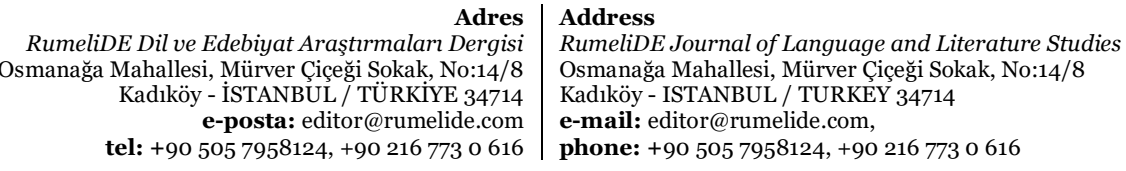


Anne 2: Hangi ayakkabıdan?

Nazlı 3: Hani geçen gün televizyon reklamlarında göstermiştim ya. Elif de giymişti bugün aynısından. Onunki pembeydi ama ben beyazından istiyorum.

Anne 3: Olmaz kızım. Biriniz bir şey alınca diğeri hemen onun aynısını alıyor. Niye birbirinizi kıskanıyorsunuz bilmiyorum ki!

Nazlı 4: Kıskanmıyorum anne. Sadece bu yıl bütün kızların ayağında o ayakkabılardan var.

Anne 4: Sende olmayıversin o zaman. Herkeste varsa ne güzelliği var o ayakkabının.

Nazli 5: Ama anne...

Anne 5: Bak hâlâ konuşuyor! Yok dediysem yok. Elifin ayakkabısından istiyor hanımefendi. Göbeğiniz beraber mi kesildi? Bir iğneyi bile kıskanıyorsunuz birbirinizden. Ayıp ayıp!.. Televizyonu açmaya korkuyorum vallahi. Reklamlarda ne görseniz ertesi gün istiyorsunuz. Her şeyiniz marka olacak, her şeyiniz en pahalısından. Elbiseyi aldık, bi de arkadaşında gördüğü ayakkabıyı istiyor. Yok sana artık hiçbir şey. Elbise de almayacağım, ayakkabı da $(62-63) ! .$.

Konuşma, Nazlı'nın e ünlü sesini uzatarak annesine seslenmesiyle başlamıştır. Ardından Nazlı, kendisine yanıt veren annesine ikinci sözcesinde ayakkabı talebini iletmiştir. "dA" bağlayıcısının kullanımından hareketle daha önce de bir talepte (elbise) bulunulduğu bilinmektedir. Konuşmanın devamında bu ayakkabının ayrıntıları hakkında bilgi verilmiştir. Annenin üçüncü sözcesiyle çatışma başlamıştır. Anne, Nazlı'nın talebini deneyimlerini (-yor biçimbirimi) gerekçe göstererek ve genelleme yaparak reddetmiştir. Yanı sıra onu olumsuz bir kişilik özelliği olarak kıskançlıkla suçlamıştır. Bu bir saldırı olarak değerlendirilebilir. Nazlı, dördüncü sözcesinde bu suçlamayı reddetmiş ve bilgilendirme yaparak annesini ikna etmeye çalışmıştır; fakat annesi bu konudaki görüşünü değiştirmemiş ve "Herkeste varsa ne güzelliği var o ayakkabının." yargısıyla gerekçelendirmiştir. Beşinci sözcesinde ise Nazlı'nın itiraz ve yalvarma içeren sözcesi yarım kalmıştır. Annesinin, Nazlı'nın sertçe sözünü kestiği ve sinirli bir biçimde söylenmeye başladığı, bolca genellemelere başvurarak çatışmayı kendince sonlandırdığı görülmektedir. Burada kızı ve yaşıtlarının genel kişisel özelliklerine ve davranışlarına yönelik küçültme, olumsuzlama hatta ayıplama yapılmıştır. Siz dilinin kullanımı bu yorumun destekleyicisi olarak nitelendirilebilir. Sonunda ise Nazlı, daha önceden alınması uygun görülen elbiseden de mahrum kalmıştır.

"Çifte Kavrulmuş Bir Hikâye" adlı sonuncu öyküde ise yemek yemeyi çok seven ikiz kardeşlerin çatışması konu edilmiştir:

Doğancan 1:

Suatcan 1:

Doğancan 2:

Suatcan 2:

Doğancan 3:

Suatcan 3:

Doğancan 4:

Suatcan 4:

Anne 1:

Suatcan 5:

Doğancan 4:

Anne 2:

\section{Çekil önümden Suatcan!}

Asıl sen çekil! Ben senden büyük sayılırım, önce benim geçmem lazım.

Hadi be! Benden beş dakika önce doğmuşsun sadece...

Tamam! Kendi ağzınla söylüyorsun. Senden önce doğmuşum işte. Yani ben büyük sayılırım.

İkizlerin büyüğü küçüğü olmaz bir kere.

Tamam. Senin dediğin olsun. Ama bak, yemek bizi bekliyor!..

Doğru söylüyorsun. Hadi önden geç o zaman. Ama tavuğun göğsü benim olacak.

Bana göre hava hoş. Tavuğun her yerini severim ben.

Yavaş çocuklar, yavaş! Bekleyin! Önce çorbanızı için.

Onunki daha çok ama!

Hayır bi kere, senin tarafına daha çok koydu!

Eh yani çocuklar! Hep birbirinizin lokmasında gözünüz.
Adres
RumeliDE Dil ve Edebiyat Araştırmaları Dergisi
Osmanağa Mahallesi, Mürver Çiçeği Sokak, No:14/8
Kadıköy - İSTANBUL / TÜRKIYYE 34714
e-posta: editor@rumelide.com
tel: +90 505 7958124, +90 2167730616

RumeliDE Journal of Language and Literature Studies

Osmanağa Mahallesi, Mürver Çiçeği Sokak, No:14/8

Kadıköy - ISTANBUL / TURKEY 34714

e-mail: editor@rumelide.com,

phone: +90 $5057958124,+902167730616$ 


\begin{abstract}
Suatcan 6: Tatlı olarak ne var?
Doğancan 5: $\quad$ Ben de istiyorum.

Anne 3: Tatli yok!

Doğancan 6: $\quad$ Baklava kutusu değil mi oradaki?

Anne 4: $\quad$ Akşama misafir gelecek, baklavayı da o zaman yersiniz.

Suatcan 7: $\quad$ Akşam senin baklavanı da ben yiyeceğim.

Doğancan 7: Zor o biraz.

Anne 5: $\quad$ Yeter artık, ayrılın bakiimm! Aaaa!.. Başımı ağrıttınız. Anlaşıldı, birlikte durmayacaksınız siz. Suatcan, sen salona geç. Doğancan sen de şuraya otur. Açıp ödevlerinizi bitirin (69-72).
\end{abstract}

Konuşmanın doğrudan çatışma ile başladığı görülmektedir. Çatışmanın kaynağı ikiz kardeşlerin oldukça aç olup mis gibi bir tavuk kokusu almasıdır. Bu nedenle yemeğe hızla ulaşma çabasıyla Doğancan, Suatcan'ı itekleyerek kaba kuvvete başvurmuştur. Suatcan ise aksini iddia ederek bu iddiasını büyük olmasına yani ondan daha önce doğmasına bağlayarak gerekçelendirmiştir. Doğancan, buna itiraz etmiş ve beş dakika önce doğmasını "sadece" belirtecini de kullanarak küçümsemiştir. Yani bu, büyütülecek, ayrıcalık sağlayacak bir durum değildir. Suatcan, ikinci sözcesinde Doğancan'ın bir önceki sözüne gönderimde bulunarak hakhlığım vurgulamıştır. Doğancan, iddiasından taviz vermeyerek (I/A)r biçimbirimiyle genelleme ve itiraz içeren "İkizlerin büyüğü küçüğü olmaz bir kere." yargısını ileri sürmüştür. Bir bakıma orta yolu bulmaya çalıştığı da söylenebilir. Yani gizil bir geri adım atmadan söz edilebilir. Buraya kadar ise düşünce ve değerlendirmelerinde takıl kaldıkları ve aynı noktaları dillendirip yineledikleri açıktır. Ardından Suatcan da açlı̆ı̆ etkisiyle açıkça geri adım atmış ve ikisi için ortak olan yemek konusunu öne sürmüştür. Bu yaklaşım, Doğancan üzerinde etkili olmuş ve dördüncü sözcesinde ona hak vermiştir; fakat anlaşma için tavuğun göğsünü yeme şartını ileri sürmüştür. Suatcan da bu talebi kabul etmiş ve aralarında taviz yoluyla anlaşma sağlanmış, ilk çatışma sona ermiştir. Diğer çatışma ise yemek sırasında gerçekleşmiştir. Konuşmaya anne de eklenmiştir. Anne ilk sözcesinde söylenerek ikizleri yavaş olmaları ve tavuk öncesinde çorba içmeleri konusunda uyarmıştır. Suatcan ise memnuniyetsizliğini dile getirerek itirazda bulunmuştur, ona göre Doğancan'ın çorbası daha çoktur. Suatcan bu iddiayı kabul etmeyip aksini ileri sürmüştür. Bu çatışmanın daha da alevlenmemesi için egemen güç olan anne devreye girmiş ve ikinci sözcesinde bu durumdan şikayetini belirterek çatışmayı sonlandırmıştır. Diğer ve son çatışmanın tatlı konusu üzerinden başladığı görülmektedir. Annenin üç ve dördüncü sözcelerine bakıldığında çatışmayı önleyecek biçimde geçici, net ve kısa yanitlar vermeye ya da sözce üretmeye çalıştı̆̆ görülmektedir. Konuyu kapatmak için elinden geleni yapmaktadır; fakat ikizlerin yedinci sözcelerine bakıldığında bu noktada tam olarak başarılı olamadığı söylenebilir. Suatcan, odalarına giderken kardeşini, onun baklavasını da yiyeceği konusunda tehdit ederek kışkrrtmıştır. Doğancan da benzer olarak karşılık verip itiraz etmiştir. Sonrasında aralarında gerçekleşen tekmeleşme, boğuşma vb. fiziksel güç kullanımı nedeniyle anne, duruma isyan etmiş ve otorite konumunu kullanarak yeniden düzenleme yoluna gidip çocukları farklı odalara göndererek yani uzaklaştırma yaparak çatışmayı sonlandırmıştır. Son sözcede olduğu gibi genellikle annenin sözcelerinde ikizlerin olumsuz davranışlarımı ve bu davranışlarından rahatsızlığını dillendirdiği, onları kontrol altında tutmaya çalıştığı söylenebilir; çünkü ikizler çoğu zaman birbirlerine karşı saldırı durumundadır.

\title{
Sonuç ve tartışma
}

Çalışmada araştırma kapsamına alınan Alacağımız Olsun adlı yapıttaki çatışma içerikli konuşmalar, söylem çözümlemesine tabi tutulmuş ve bu yapitta yer alan öyküler üzerinden çocuk kitaplarında

RumeliDE Dil ve Edebiyat Araştırmaları Dergisi $\quad$ RumeliDE Journal of Language and Literature Studies Osmanağa Mahallesi, Mürver Çiçeği Sokkak, No:14/8 $\quad$ Osmanağa Mahallesi, Mürver Çiçeği Sokak, No:14/8 Kadıköy - ÍSTANBUL / TÜRKIYE 34714 Kadıköy - ISTANBUL / TURKEY 34714 e-posta: editor@rumelide.com e-mail: editor@rumelide.com, tel: +90 505 7958124, +90 2167730616 phone: +90 505 7958124, +90 2167730616 
çatışma söyleminin nasıl oluşturulup geliştirildiğinin belirlenmesi amaçlanmıştır. Bu bağlamda çözümlemeler sonrasında şu çıkarım, yorum ve değerlendirmeler yapılabilir:

"Her İnsanın Bir Öyküsü Vardır" adlı öykünün ilk çatışmasında, çocuklar arasında bir fikir ayrılı̆̆ının yaşandığı görülmektedir. Öğretmenin yaptığı bilgilendirmede ileri sürdüğü fikre çocuklardan birinin doğrudan değil, fısıltıyla- itiraz etmesi sonrasında çatışma başlamış, benzer düşünceye sahip olduğu için başka bir çocuğun itirazı desteklemesiyle çatışma tırmandırılmıştır. Bu tırmanmada fiziksel güç ve argo içeren sözcelerin üretilmesinin de etkisi vardır. Bu iki çocuk, bir taraf oluşturup gruplaşmışlardır. Başka bir çocuk ise iddialarında tutarsızlık ve mantıksızlık olduğunu ileri sürerek alay yoluyla bilgilendirme yapmıştır; fakat özellikle ilk itirazı yapan çocuğun düşüncesinde ısrarcı olduğu açıtır, bu nedenle onun görüşünü yinelemesiyle çatışma sonlanmıştır. Aslında itiraza konu olan yargıyı ortaya atan kişi öğretmendir; fakat öğretmenin konumu nedeniyle öğrenciler, doğrudan fikirlerini öğretmene karşı yönlendirememişlerdir. Bu nedenle çatışmanın odağının kaydığı ve doğrudan muhatabı ile yapılamadığı yorumu da yapılabilir. Söz konusu konuşmanın devamında öğretmenin ılımlı, hoşgörülü, eleştiriye açlk bir konum alması sonucunda çocukların öğretmenden farklı olan düşüncelerini açıcça ifade edebildiği görülmüştür. Bu noktada çocuk-yetişkin çatışması başlamıştır. Öğretmen sorduğu sorularla öğrencileri bilgilendirerek görüş geliştirmeye çalışsa da öğrencilerin düşüncelerini gerekçelendirmeler yaparak yineleyip sahiplendikleri görülmektedir. Son olarak ise öğretmen, konuyu ve iddiasını özetleyen ayrıntılı bir açıklama yaparak çatışmayı sonlandırmıştır. Öykü ise ders zilinin çalması, öğretmen tarafından öğrencilere ödev verilerek ve öğrencilerin bu ödevi anlamlandırma çabalarıyla sonlandırılmıştır. Yani öykü içerisinde kişiler arasında yaşanan çatışmaların tam olarak çözüme kavuşturulamadığı, bilgilendirme yoluyla kapatıldığı söylenebilir.

"Dünyanın Bütün Dedeleri Birleşin" adlı öyküde ise çatışma içerikli konuşma, dedeler yani yetişkinler arasında yaşanmıştır. Çatışma, bir dedenin diğerine ima yoluyla gönderimde bulunması ve diğer dedenin de bunu karşı iddia ile yalanlamasıyla başlamış; karşılıklı itham, inkâr, küçültme ve hakaret içerikli sözcelerle tırmandırılmıştır. Özellikle dedelerin, sözleriyle karşı tarafı torununun gözünde küçültmeye, aşağılayarak saygınlığını zedelemeye çalıştıkları açıktır. Yanı sıra saplantılı bir biçimde iddialarını sürekli yinelemişler ve çatışmanın dozunu giderek artırmışlardır. Hatta fiziksel olarak da yakınlaşmışlardır. Çatışmanın sonlandırılması ise üçüncü bir tarafın müdahalesi ile sağlanmıştır. Yani çatışmanın taraflarca çözülemediği açıktır. Bu müdahale sonrasında tarafların birbirleriyle tavla oynayarak kozlarını paylaşması sonucu olumsuz duygularının olumluya dönüştügüu, dolayısıyla öyküdeki çatışmanın çözüme kavuşturulup sonlandırıldığı görülmektedir.

"İntikam Dondurma Gibidir: Soğuk ve Tatlı" adlı öyküdeki çatışma, aile üyeleri olan anne-baba yani yetişkinler arasındadır. Çatışmanın kaynağı eve gelen yüksek telefon faturası ve ailenin bu faturadan henüz haberinin olmasıdır. Söz konusu faturanın ailenin eline ulaşması sonrası özellikle babanın olumsuz duygularını, yani öfkesini dizginleyemeyip söylenmeye devam etmesiyle çatışma içerikli konuşmanın başladığı söylenebilir. Babanın çatışma başlatıcı ilk sözcesine karşın annenin tavrı sakin ve çözüme yöneliktir; fakat baba onun sözünü keserek ve suçlayıcı bir tavırla saldırıya geçmiş, ardından annenin inkâr ve haklılığını kanıtlayıı tavrıyla karşılaşmıştır. Çatışma, babanın hatasını anlayıp geri adım atmasıyla ve çözüm planlarını sunup yeniden düzenleme yapmasıyla sona ermiştir. Bu noktada çatışmanın çözüme kavuşturulduğunu söyleyebilmek mümkündür. Öykü ise bu çatışma içerikli konuşma sonrasında babanın oğluna ceza vermesinin ardından oğlanın, ona iftira atan ablasından öç alması ve bundan pişmanlık duyması, yani iç çatışma yaşamasıyla sonlanmıştır. Dolayısıyla öyküde var olan çatışmanın, çözüme kavuşturulduğu söylenebilir.

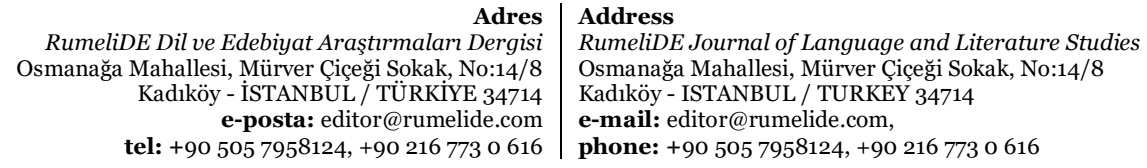

Adres
RumeliDE Dil ve Edebiyat Araştırmaları Dergisi tel: +90 505 7958124, +90 2167730616 
"Alacağınız Olsun" öyküsündeki çatışma içerikli konuşma, önce abi-kardeş yani çocuklar arasında, ardından kardeş-anne yani çocuk ve yetişkin arasında gerçekleşmiştir. Öykü doğrudan bu çatışma içerikli konuşma ile başlamıştır. Abi doğrudan öfkesini belirterek kardeşine karşı saldırıya geçmiş, kardeşinin savunmaya geçmesine dahi izin vermeden hakaret, argo kullanımına ve fiziksel güç uygulayarak kardeşini ortamdan uzaklaştırmış, bu ikili arasındaki çatışma daha başlamadan doğrudan sonlanmıştır. Kardeş ise abisine karşı savunma yapamadığı ve konum olarak abisinden aşağıda kaldığı için daha üst konumdaki kişiye yani annesine şikâyette bulunmuştur; fakat annenin beklenen tepkiyi vermemesi ve diğer tarafı savunması sonucu kardeş, sürekli itiraz ederek ve haklılığını vurgulama yoluyla yeni iddialar ileri sürüp suçlamalar yaparak çatışmayı tırmandırmıştır. Anne ise her itiraza ve suçlamaya karşı farklı sözcelerle iddiasını gerekçelendirerek ve bilgilendirme yaparak tartışmayı dengede tutmaya yani yeniden düzenleme yapmaya çalışmıştır; fakat kardeşin düşüncesinde ısrarcı olması annenin geri çekilip ortamdan uzaklaşmasına neden olmuştur. Yani çatışma içerikli konuşma çözümsüz kalmıştır; fakat daha sonra kardeş, abisiyle ilgili yazdığı şiiri okumak için babasının yanına gönderilmiş, okunan şiirin az önce tartışma yaşayıp çatıştığı anne ve abisi tarafından takdir edilmesiyle öykü sonlandırılmıştır. Dolayısıyla öyküde var olan çatışmanın çözüme kavuşturulduğu söylenebilir.

"Kendi Modanı Kendin Yarat" öyküsünde ise çatışan kişiler anne ile kızıdır; yani çocuk-yetişkin çatışması yaşanmıştır. Konuşmada çatışma, çocuğun taleplerini iletmesi ve annesinin bu taleplere karşı verdiği olumsuz tepkiyle ve suçlamalarla başlamıştır. Ardından çatışmanın annenin suçlayıcı ve genelleyici iddialarıyla ve çocuğun ise gerekçelendirme yoluyla yaptığı savunmalarıyla sürdürüldü̆ğü görülmektedir. Anne, düşünce ve değerlendirmelerinde saplanıp kaldığı için çocuğun savunmasını çoğu zaman engellemiş; söylenmeye, iddialarını sıralamaya ve haklılığını vurgulamaya devam ederek çatışmayı sonlandırmıştır. Dolayısıyla çatışmanın çözüme kavuşturulamadığı söylenebilir. Öykü ise babanın, çocuğa bir elbise hediye etmesi ve bu elbisenin partide diğer çocuklar tarafından farklı bulunup beğenilmesi ve annenin haklı çıkmasıyla sonlanmıştır. Dolayısıyla öyküde var olan çatışmanın, çözüme kavuşturulduğu söylenebilir.

"Çifte Kavrulmuş Bir Hikâye" öyküsünde ise çatışanlar ikiz kardeş olan çocuklardır. Tüm konuşma boyunca çatışmanın kaynağı yemektir. Yemeğe yetişme, yemeğin miktarı vb. üzerinden çocuklar sürekli rekabet halindedir. Bu çatışmada sürekli suçlayıcı iddia-itiraz-karşı suçlayıcı iddia-karşı itiraz biçiminde bir döngü vardır. Kimi zaman tehdit ve fiziksel güç kullanımı da olmuştur. Anne ise çatışma sürecinde üçüncü taraf olarak müdahale ve kontrol görevi üstlenmiştir, yani yeniden düzenleme yapmaktadır. Çocukların da kimi zaman taviz yoluyla çıkara dayalı anlaşma sağladıkları görülmüştür; fakat bu durum anlıktır. Ardından uzun süre geçmeden yeniden bir çatışma ortaya çıkmıştır. Çatışma, annenin müdahalesi sonucu çocukları birbirinden uzaklaştırmasıyla sonlanmıştır. Öykü ise çocukların çatışmada konusu edilen baklavayı yiyip hastaneye kaldırılmaları sonucunda pişman olmaları ile sonuçlanmıştır. Dolayısıyla öyküde var olan çatışmanın, çözüme kavuşturulduğu söylenebilir.

Kurmaca metinlerde başkişi; kardeş, anne-baba, ailesinden başka birileri, arkadaşları, aynı ortamı paylaşıp arkadaş olmadığı yaşıtları, öğretmeni, tanıdığı başka bir yetişkin ya da insan özellikleri taşıyan bir varlık ile çatışabilir. Bu tür çatışmalar başkişinin başka bir kişiyle çatışması yani kişilerarası çatışma olarak adlandırılabilir (Karagöz, 2014: 24). Çözümlemesi yapılan konuşmalara bakıldığında başkişi odağında öğretmen-öğrenci, öğrenci-öğrenci, dede-dede, anne-baba, anne-kız, abi-kardeş, anne-oğul, ikizler gibi farklı yönde çocuk-çocuk, çocuk-yetişkin, yetişkin-yetişkin çatışmalarına yer verildiği görülmektedir. Çatışmaların genellikle fikir ayrılığı-uyuşmazlı̆̆ı ve bir şeyi paylaşamama kaynaklı olduğu söylenebilir; fakat farklı olaylar üzerinden kurgulanmışlardır. Bilgilendirme, ima, isyan, öfke, rekabet, talep içeren sözcelerden herhangi birisi çatışmayı tetikleyici görev üstlenmiştir. Bu sözcelerin

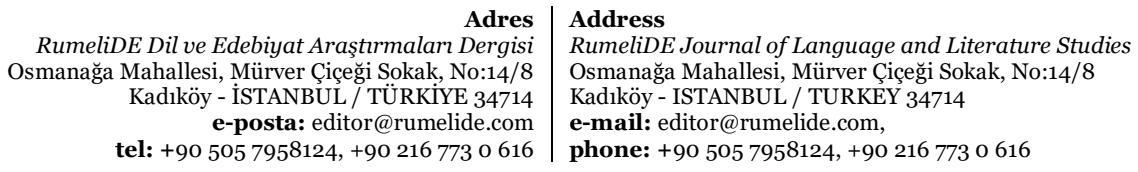


kimisi doğrudan saldırı, kışkırtma amaçlı iken kimisi de herhangi bir art niyet içermemektedir; fakat tümü bir itiraz, ret, karşı çıkış, başkaldırı ve/veya savunma ile karşılanmıştır. Dolayısıyla konuşmalardaki çatışmaların bu yolla başlatıldığını söyleyebilmek mümkündür. Söz konusu çatışma içerikli konuşmaların benzer döngüde iddia-suçlama, inkâr, karşı iddia-suçlama, savunma biçiminde ilerlediği ve kimi zaman az da olsa hakaretlerle tırmandırllıp sürdürüldüğü görülmüştür. Kişiler, haklılığını ve karşı tarafın haksızlığını kanıtlama çabasındadır. Bu bağlamda tarafların sıklıkla düşüncelerine saplanıp kalarak farklı sözcelerle görüss ya da tezlerini yineledikleri söylenebilir. $\mathrm{Bu}$ süreçte kanıtlama amaçlı olarak deneyimleri belirtmek üzere -yor ve genelleme yapmak içinse -(I/A)r ve -DIr biçimbirimlerine başvurulmuştur. Yanı sıra iddiayı reddetme amaçlı olumsuzluk içeren dilsel yapıların ve sözcüklerin sıklıkla kullanıldığı görülmüştür. Çocuklar arasındaki çatışmalar, genellikle üçüncü bir taraf olan yetişkin müdahalesiyle yeniden düzenleme ya da mesafe, uzaklaştırma yoluna başvurularak sonlandırılmıştır. Her ne kadar çocuklar arasında olan kimi tartışmalarda çıkara dayalı ve taviz yoluyla anlaşmaya varıldığı görülse de çatışma içerikli konuşmanın bütününe odaklanıldığında yine bir yetişkin müdahalesine gerek duyulduğu saptanmıştır. Aksi durumda çocukların tartışmalarının giderek tırmanacağı ve ısrarlarının artacağı düşünülebilir. Bu amaçla genellikle emir ve istek ile gelecek zaman kiplerine başvurulduğu gözlemlenmiştir. Kimi zaman da taviz amaçlı olarak dilek ve şart kipinden yararlanılmıştır. Çocuk ve yetişkin arasındaki çatışmalarda ise konuşmalar, yetişkinin bilgilendirme ya da yeniden düzenleme yaparak bir bakıma çocuğun konuşmasını kesip kendi söyleyeceklerini tam olarak söyleyip bitirmesiyle sonlandırılmıştır. Yani yetişkin, bu noktada kendi konumunu kullanmıştır. Aslan'ın (2006: 214) çeşitli çocuk kitaplarındaki çocuk-yetişkin çatışmalarını incelediği çalışmasında da benzer bir sonuca ulaşıldığı görülmektedir. İncelenen yapıttaki yetişkinler arasındaki çatışmaların birinde üçüncü kişi müdahalesine gereksinim duyulmuşken diğerinde taraflardan biri geri adım atıp diğerinin haklılı̆̆ını kabullenmiştir. Yapıtta, türü (çocuk-çocuk, çocukyetişkin, yetişkin-yetişkin) ne olursa olsun özellikle yaşanan çatışmaların çocuk üzerindeki duyuşsal, bilişsel ve davranışsal etkilerinin -kimi zaman yazar kimi zaman da çatışma içerisindeki çocuğun sözceleri aracılığıyla- yansıtılması çocuğa görelik ve çocuk gerçekliği ilkeleri bağlamında oldukça önemli bir ayrıntı olarak değerlendirilebilir. Bu sayede "çocuk okur kitaplarda yer alan olumlu ve olumsuz ortam ve bu ortama dair tavır ve tutumları kendi yaşadıklarıyla karşılaştırabilir ve kahramanların yaşamı aracılığıyla kendi yaşadıklarını irdeleyip yorumlayabilir" (Büyükışı, 2019: 76).

Alanyazında konuyla ilgili gerçekleştirilen çalışmalara bakıldığında çocukların çatışma içerikli -gerçek ve doğal olan- konuşmalarında çoğunlukla yineleme, kışkırtma-tırmandırma, tersine çevirme gibi yollara başvurdukları görülmüştür. Çocukların sıklıkla çatışma içerikli konuşmalar ürettikleri ve "hayır" ya da "değil" dilbilgisel yapıları ile yineleyici ifadelere başvurarak hızlıca, doğrudan ve herhangi bir gecikme yaşamadan söylenenin tersini iddia ettikleri ya da karşı çıkma eğiliminde oldukları bulgulanmıştır. Çatışmalar; çelişme rutinleri, iddialar, meydan okuma, tehdit, hakaret ardından farklı çelişkiler, iddialar ile tehdit ve hakaret döngüsü biçiminde gerçekleşmiştir. Çocuklar, bir çatışmayı başlatmak ve/veya sürdürmek için sözdizimsel, sözcüksel ve sesbilimsel olarak yinelemelere ve çokça değiştirime başvurmaktadırlar. $\mathrm{Bu}$ başvurumların çatışmayı tırmandırma, hareketlendirme, şiddetlendirme amacıyla olduğu söylenebilir. Bir bakıma kışkırtma olarak da değerlendirilebilir (Akt. Kakavá, 2001: 651-652). Yetişkinler de benzer biçimde konuşmalarında, çatışma ilerledikçe çatışmayı tırmandırıcı ve hakaret içeren sözcelere yer vermektedir (Kuo, 1992). Kurgusal bir metinde yer alan doğal olmayan- çatışma içerikli konuşmaları çözümleyen bu çalışmadan elde edilen sonuçların yukarıda paylaşılan araştırmaların sonuçlarıyla koşutluk gösterdiği görülmektedir. Özellikle çocukların çatışma sırasındaki eylem ve tutumlarının seçilen yapıta yansımış olması, çocuk gerçekliğinin dikkate alınması bağlamında önemli bir nokta olarak değerlendirilebilir; fakat her ne kadar iletişim sürecinde kişiler arasında çatışma içerikli konuşmaların yer alması normal, olağan olarak kabul edilse de söz konusu

Adres Address

RumeliDE Dil ve Edebiyat Araştırmaları Dergisi $\quad$ RumeliDE Journal of Language and Literature Studies

Osmanağa Mahallesi, Mürver Çiçeği Sokak, No:14/8 Osmanağa Mahallesi, Mürver Çiçeği Sokak, No:14/8

Kadıköy - İSTANBUL / TÜRKIYE 34714 Kadıköy - ISTANBUL / TURKEY 34714

e-posta: editor@rumelide.com $\quad$ e-mail: editor@rumelide.com,

tel: +90 $5057958124,+90216773$ o 616 phone: +90 505 7958124, +90 2167730616 
çatışmaların sağlıklı bir biçimde yönetilmesi yani şiddet içermeden olumlu niyetle sürdürülüp anlaşma, uzlaşmaya varılarak sonlandırılması "çocukların her gün işbirliği içinde geçirdiklerinden daha fazla zamanı çatışma içerisinde geçirmeleri " (Akt. Jensen-Campbell vd., 2003: 1060) nedeniyle barış eğitimi bağlamında önemlidir. Harris ve Morrison'a göre (Akt. Sağkal, Türnüklü ve Totan, 2012: 1448) barış eğitimi; "sevgi, şefkat, saygı, şiddetsizlik gibi tutumların kazandırıldığı hem felsefi hem de dinleme, yansıtma, problem çözme, işbirliği ve çatışma çözümü gibi becerilerin kazandırıldı̆̆ı süreç boyutlarından" oluşmaktadır ki Rehber ve Atıcı'nın (2009) çalışmaları da empati kurma eğilimi yüksek çocukların çatışmaları, yapıcı bir biçimde sonuçlandırdıklarını ve daha sağlıklı iletişım kurabildiklerini göstermiştir. İncelenen yapıttaki öykülerde kimi çatışma içerikli konuşmalar çözümsüz olarak veya üstü kapatılarak, örtülerek sonlansa da çoğunlukla öykülerin sonunda olay örgüsü içerisinde dinleme ve yansıtma yoluyla kişiler arasında empati kurulduğu bu bağlamda yaşanan çatışma ve sorunların çözüldüğ̈̈, barışın sağlandığı görülmüsştür. Dolayısıyla incelenen yapıtın barış eğitimini önemsediği yorumunu yapmak mümkündür ki "kendisiyle barışık bireylerin yetiştirilmesi adına metinlerde içsel barış iletilerine sıklıkla yer verilmesi" barış eğitimi açısından önemli bir gerekliliktir (Çelik, Demirgüneş ve Türnüklü, 2016: 250).

Çocuğa okuma kültürünün kazandırılması amacıyla Türkçe derslerinde daha çok metinlerin kendilerinin okunması, öğrencilerin metin üzerine öznel düşünce ve alımlamalarının alınması önemlidir. Burada işaretlenen okuma biçimi ise bilinçli ve eleştirel bir okumadır. Bu sayede farklı metinlerin nasıl okunacağı, anlamlandırma için nasıl bir yöntem izleneceği konusunda bilinçlenme sağlanacaktır (Dilidüzgün, 2018: 24). Dilidüzgün ve diğerlerinin (2019b) çalışmasında da her metin türünün farklı strateji ve yöntemler kullanılarak okunması gerektiği sonucuna ulaşılmıştır. Serimdüğüm [çatışmanın doruk ve dönüm noktası (Akt. Karagöz, 2014: 22)] ve çözüm bölümlerinden oluşan öykü de bu metin türlerinden biridir. İncelenen yapıtta yer alan çatışma içerikli konuşmaların kimi zaman öyküye giriş yapma amacıyla serim, kimi zaman olay örgüsünün ve çatışma ya da sorunun ayrıntılandırılması için düğüm, kimi zamansa öyküdeki sorunu, çatışmayı çözüme kavuşturabilme gerekçesiyle çözüm bölümünde yer aldığı görülmektedir. Dolayısıyla yazınsal bir metin türü olan öyküde çatışma içerikli konuşmaların sıklıkla yer aldığını söyleyebilmek mümkündür. "İyi kurgulanmış bir öyküde, anlama ortak edilen okur, öyküdeki olayları ve karakterleri tanıdığında, öyküdeki çatışmanın nasıl sonuçlar doğurabileceğini de düşünmeye başlar; öyküdeki düğüm çözümü hakkında, yazarın sunduğu ipuçlarından da yararlanarak bazı çıkarımlarda bulunur" (Sever, 2012: 138). Bu açıdan bakıldığında Türkçe derslerinde öykü gibi kurmaca nitelikli metinler üzerine gerçekleştirilen etkinliklerde söylem çözümlemesinden yararlanılarak konuşma sırasında çatışmayı başlatan, sürdüren ve çözümlendiren ya da çözümsüzlüğe uğratan kişisel adımlara, stratejilere; başvurulan dilsel araçların fark edilmesine yönelik görevlerin geliştirilip uygulanması önemlidir. Yanı sıra iletişim ilkeleri odağında çatışma söyleminin değerlendirilmesi ve sınıf içerisinde gerçekleştirilecek etkinliklerle çatışma sürecini sağllklı bir biçimde yönetmeye yönelik görevlere yer verilmesi öğrencilerin iletişimsel becerilerinin gelişimine katkı sunacaktır. "Yaşanan çatışmaların iyi yönetilmesiyle birlikte, bireyin kavram, beceri ve davranış edinim süreçleri de desteklenebilmektedir" (Aksoy, 2020: 658). Çalışmanın bu bağlamda Türkçe ve sınıf öğretmenlerine yönlendirici olacağı düşünülmektedir.

\section{Kaynakça}

Ak Başoğul, D. (2018). Türkçe Öğretmenlerinin ve Önerdikleri Kitaplarm Söylemleri Bağlamında Okuma Kültürü Anlayışı: Bìr Durum Çahşması (Doktora Tezi). Marmara Üniversitesi, İstanbul.

Aksoy, P. (2020). Masallarda Yer Alan Çatışmalara İlişkin Bir İnceleme: Aytül Akal'ın Okul Öncesi Masallar Dizisi Örneği. Ana Dili Ĕ̆itimi Dergisi, 8(3), 657-674.

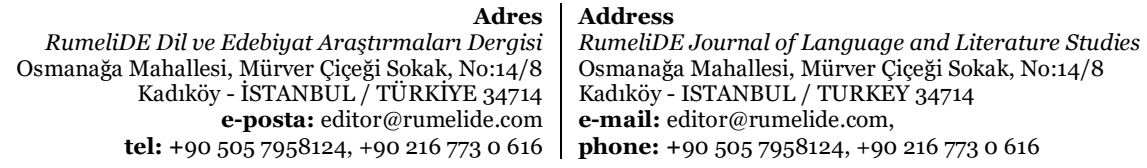


Aslan, C. (2006). Türk Çocuk Yazınında Çocuk-Yetişkin Çatışmasının Yer Aldığı Kimi Yapıtların İncelenmesi. Ankara Üniversitesi Eğitim Bilimleri Fakültesi Dergisi, 39(2), 193-216.

Aslan, C. (2014). Barış Eğitiminde Çocuk ve Gençlik Edebiyatı. Şener, T. (Yay. Haz.). Okul Kültürü ve Çocuk - VII. Ulusal Çocuk Kültürü Kongresi Bildirileri (381-399). Ankara: Ankara Üniversitesi Çocuk Kültürü Araştırma ve Uygulama Merkezi.

Burr, V. (2012). Sosyal İnşacılık (Çev. Ed. S. A. Arkonaç) (2. Baskı). Ankara: Nobel Akademik.

Büyükışı, E. (2019). Nur İçözü’nün Çocuk Kitaplarındaki Kişilerarası Çatışmalar ve Çatışma Çözme Süreçleri (Yüksek Lisans Tezi). Burdur Mehmet Akif Ersoy Üniversitesi, Burdur.

Büyüköztürk, Ş. (2012). Örnekleme Yöntemleri. http://cv.ankara.edu.tr/duzenleme/kisisel/dosyalar/21082015162828.pdf adresinden 01.07.2021 tarihinde edinilmiştir.

Coulthard, M. (Ed.) (2002). Advances in Spoken Discourse Analysis. London: Taylor \& Francis eLibrary.

Creswell, J. W. (2014). Araştırma Deseni - Nitel, Nicel ve Karma Yöntem Yaklaşımları (4. Baskıdan çev.) (Çev. Ed. S. B., Demir). Ankara: Eğiten Kitap.

Çakır, A. (2014). Söylem Analizi Ne Demek İstiyorsun? Konya: Palet.

Çelik, T., Demirgüneş, S. ve Türnüklü, A. (2016). Barış Eğitimi Kapsamında Türkçe Ders Kitaplarındaki Metinlerin İncelenmesi. Dilidüzgün, S. (Ed.). Kuram ve Uygulama Bağlamında Türkçe Eğitimi (241-251). Ankara: Anı Yayıncılık.

Çubukçu, H. (2014). Etkileşimsel Söylem: Çözümleme Yaklaşımları - Uygulamalar. Ankara: Akademisyen Kitabevi.

Dilidüzgün, S. (2018). Çağdaş Çocuk Yazını (3. Baskı). Ankara: TUDEM.

Dilidüzgün, Ş., Çetinkaya Edizer, Z., Ak Başoğul, D. ve Karagöz, M. (2019a). Türkçe Öğretiminde Metin Türüne Uygun Okuma Eğitimi. Mersin Üniversitesi Ĕ̆itim Fakültesi Dergisi, 15(1): 165-185.

Dilidüzgün, Ş., Çetinkaya Edizer, Z., Ak Başoğul, D., Karagöz, M. ve Yücelşen, N. (2019b). Metin Türü Bağlamında Okuma Yöntem-Teknikleriyle Üstbilişsel Okuma Stratejilerini ìlişkilendirme Çalışması. Uluslararası Türkçe Edebiyat Kültür Eğitim Dergisi, 8(3), 1796-1816.

Fairclough, N. (2006). Discourse and Social Change. USA: Polity Press.

Gloning, T. (2005). Early Modern Controversies and Theories of Controversy (263-282). Barrotta, P. \& Dascal, M. (Ed.) Controversies and Subjectivity. Philadelphia, PA, ABD: John Benjamins Publishing Company.

Göçmen, D. E. (2015). Alacağınız Olsun. İstanbul: Altın Kitaplar.

Günay, D. (2013). Söylem Çözümlemesi. İstanbul: Papatya.

Gür, T. (2011). Türkçe Öğretmeni Adaylarının Dil Tutumları ve Dil Kullanımlarmın Söylem Çözümlemesi Yöntemi ile Betimlenmesi (Doktora Tezi). Atatürk Üniversitesi, Erzurum.

Jensen-Campbell, L. A. \& Graziano, W. G. (2005). Methodologies for Studying Personality Processes in Interpersonal Conflict. Intemational Negotiation, 10, 165-182.

Jensen-Campbell, L. A., Gleason, K. A., Adams, R. \& Malcolm, K. T. (2003). Interpersonal Conflict, Agreeableness, and Personality Development. Journal of Personality, 71(6),1059-1086.

Kakavá, C. (2001). Discourse and Conflict. Schiffrin, D., Tannen, D. \& Hamilton, H. E. (Ed.). The Handbook of Discourse Analysis (650-670). USA: Blackwell Publishers.

Karagöz, S. (2014). Çocuk Romanlarındaki Başkişilerin Yaşadıkları Çatışmaları Çözme Yöntemlerinin İncelenmesi (Doktora Tezi). Ankara Üniversitesi, Ankara.

Karahan, F. (2009). Bireyler Arasında Çatışma İçerikli Konuşmaların Söylem Çözümlemesi. Dilbilim Araştırmaları, 1, 11-34.

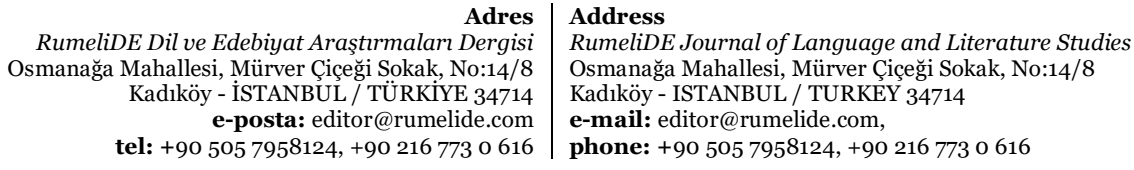


Kocaman, A. (2009). Dilbilim Söylemi (3. Baskı). Kocaman, A. (Yay. Haz.). Söylem Üzerine (1-11). Ankara: ODTÜ.

Kuo, S. H. (1992). Formulaic opposition markers in Chinese conflict talk. Alatis, J. E. (Ed.). Georgetown University Roundtable on Languages and Linguistics (388-402). Washington D.C.: Georgetown University Press.

Mayer, (2000). The Dynamics of Conflict Resolution. http://www.orgwise.ca/sites/osi.ocasi.org.stage/files/resources/The\%20Dynamics\%20of\%20C onflict\%20Resolution.pdf adresinden 20 Haziran tarihinde edinilmiştir.

Ozan Demir, Y. (2009). Çocuk Masallarında Kişilerarası Çatışma Çözme Süreci (Yüksek Lisans Tezi). Ankara Üniversitesi, Ankara.

Özdemir, E. (2002) Eleştirel Okuma. (5. Baskı). Ankara: Bilgi.

Rehber, E. ve Atıcı, M. (2009). İlköğretim İkinci Kademe Öğrencilerinin Empatik Eğilim Düzeylerine Göre Çatışma Çözme Davranışlarının İncelenmesi. Ç.Ü. Sosyal Bilimler Enstitüsü Dergisi, 18(1), 323-342.

Sağkal, A. S., Türnüklü, A. ve Totan, T. (2012). Kişilerarası Barış İçin Empati: Barış Eğitiminin Empati Becerilerine Etkileri. Kuram ve Uygulamada Eğitim Bilimleri, 12(2), 1447-1460.

Sever, S. (2012). Çocuk ve Edebiyat (6. Basım). İzmir: TUDEM.

Sinclair, J. \& Coulthard, M. (2002). Towards an Analysis of Discourse. Coulthard, M. (Ed.). Advances in Spoken Discourse Analysis. London: Taylor \& Francis e-Library.

Solak, Ö. (2013). Aytül Akal'ın "Babam Duymasın” Adlı Öyküsündeki Çatışma Yapısının Çocuğa Göreliği. Gültekin, A., Sivri, M., Çiftçi, Z. ve Yılmaz, B. H. (Yay. Haz.). V. Ulusal Çocuk ve Gençlik Edebiyat Yaşayan Yazarlar Sempozyum Dizisi: Çocuk ve Gençlik Edebiyatında Aytül Akal Sempozyumu Bildiri Kitabr (227-234). Ankara: Uçanbalık.

Tekdemir, G., Arkonaç, S. A. ve Çoker, Ç. (2012). Sorumluluk Atıflarında Kullanılan Konumlandırma Stratejileri. Arkonaç, S. A. (Ed.). Söylem Çalş̧maları. Ankara: Nobel.

TÜBA (2011). Türkçe Bilim Terimleri Sözlüğü-Sosyal Bilimler. Ankara: Türkiye Bilimler Akademisi.

Van Langenhove, L. \& Harré, R. (1999). Introducing Positioning Theory. https://www.academia.edu/491329/Introducing_positioning_theory adresinden 01 Şubat 2018 tarihinde edinilmiştir.

Vuchinich, S. (1987). Starting and Stopping Spontaneous Family Conflicts. Journal of Marriage and Family, 49(3), 591-601.

Yakar, Y. M. ve Yllmaz, O. (2015). Beyazbulut Dergisi'nde Yer Alan Kurgusal Metinlerdeki Karakterlerin Çatışmaları Çözme Biçimleri. Erzincan Üniversitesi Sosyal Bilimler Enstitüsü Dergisi (ERZSOSDER), ÖS-II, 57-66.

Yemenici, A. (1995). Söylem Çözümlemesinde Üç Temel Yaklaşım ve Kültürlerarası İletişimde Söylem Çözümlemesinin Önemi. Dilbilim Araştırmaları Dergisi, 152-166.

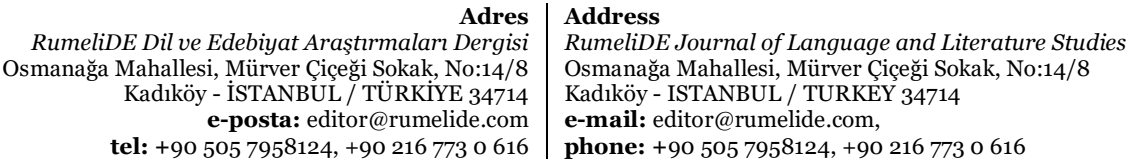

